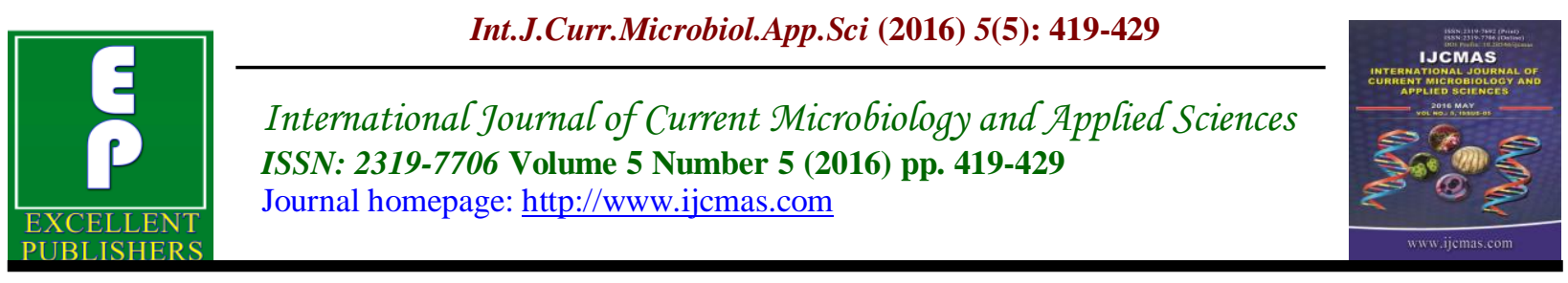

Original Research Article

http://dx.doi.org/10.20546/ijcmas.2016.505.044

\title{
Clinical, Laboratory, and Virological Profiles of Patients with Hepatitis C and B Co-infection in Upper Egypt
}

\author{
Khairy H. Morsy $^{1 *}$ and Mohamed A.A. Ghaliony ${ }^{2}$ \\ ${ }^{1}$ Tropical Medicine and Gastroenterology Department, Faculty of Medicine, \\ Sohag University, Egypt \\ ${ }^{2}$ Tropical Medicine and Gastroenterology Department, Faculty of Medicine, \\ Assiut University, Egypt \\ *Corresponding author
}

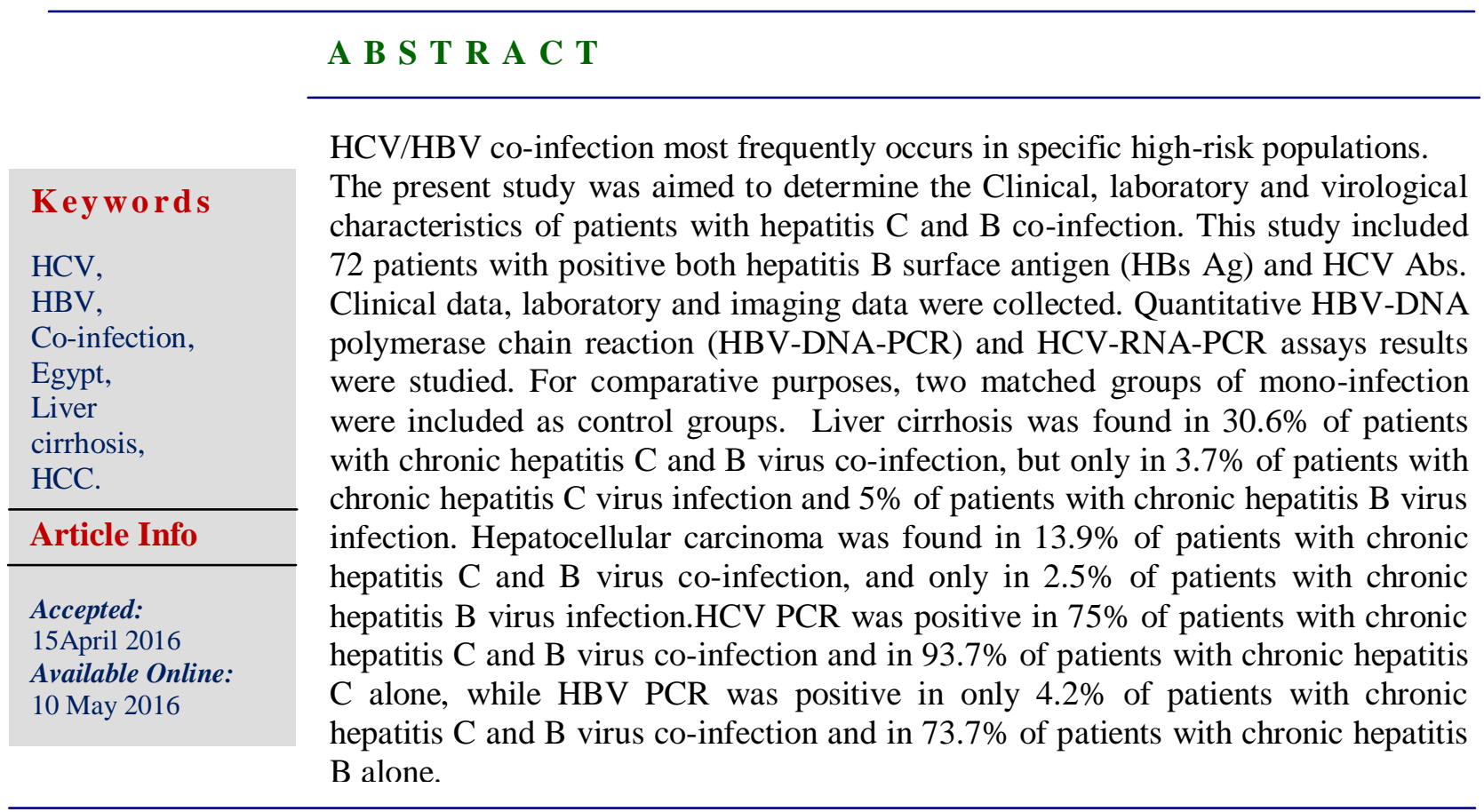

\section{Introduction}

The globally high prevalence of hepatitis $\mathrm{B}$ virus (HBV) and hepatitis $\mathrm{C}$ virus (HCV), in association with the shared routes of transmission of these viruses, explains the inevitable common finding of $\mathrm{HBV} / \mathrm{HCV}$ co-infection. Such interactions were first described when HCV infection was known as non-A, non-B hepatitis (Lee et al., 1985). It is difficult to accurately determine the number of $\mathrm{HBV} / \mathrm{HCV}$ co infected individuals and there is considerable geographical variation; it is estimated that $3-22 \%$ of chronic HBV infected patients are $\mathrm{HCV}$ antibody positive and that $2-10 \%$ of anti-HCV-positive patients are $\mathrm{HBs} \mathrm{Ag}$ positive (Chu and Lee,2008). Outside endemic areas, $\mathrm{HBV} / \mathrm{HCV}$ co-infection most frequently occurs in specific high-risk 
populations, particularly intravenous drug users, HIV-positive individuals and patients on hemodialysis (Chu and Lee, 2008).

Reports of occult HBV infection (HBs Ag negative, HBV DNA positive) suggest it is likely we underestimate the true prevalence of co-infection and implies that co-infection should be actively sought by HBV DNA testing, particularly in anti-HBc Ab-positive individuals (Chu and Lee, 2008; Cacciola et al., 1999). From both the biological and clinical points of view, a crucial question is whether HBV and HCV may interfere in the life cycle of each other in cases of coinfection. In vitro studies performed since the early 90 s had clearly demonstrated that the HCV "core" protein strongly inhibits HBV replication (Shih et al., 1993; Shih et al., 1995; Schüttler et al., 2002; Chen et al., 2003). From the virological point of view, studies showed that both HBV and HCV could interact with each other and possibly affect host immune responses (Gordon and Sherman, 2009).

Dual viral infection may occur rarely by simultaneous acute infection with both viruses or more commonly by a second acute infection in an individual already chronically infected with one hepatitis virus (superinfection). Typically, particularly in areas with high HBV prevalence, acute HCV will be superimposed on chronic HBV (Crockett, et al., 2005). Acute superinfection may provoke a fulminant hepatitis ( $\mathrm{Wu}$ et al., 1994), or may lead to a chronic dual hepatitis with sequelae including cirrhosis and hepatocellular carcinoma (HCC). Rarely, superinfection with HCV may result in clearance of HBV (Sheen et al., 1992). Despite the relatively large disease burden, knowledge regarding the virological interactions, clinical consequences of coinfection and optimum therapy remains incomplete.
The aims of the current study were:

Description of clinical, laboratory, and virological profiles of patients with chronic hepatitis $\mathrm{C}$ and $\mathrm{B}$ virus co-infection.

Comparing clinical, laboratory, and virological profiles of patients with chronic hepatitis $\mathrm{C}$ and $\mathrm{B}$ virus co-infection with those of patients with either chronic (HCV) infection or chronic (HBV) infection alone.

\section{Patients and Methods}

This is a hospital based; descriptive, retrospective analytic study which was conducted to evaluate the data registry of the Viral Hepatitis outpatient clinic in both the Assiut University Hospital and Sohag University Hospital, Egypt, during the period between January 2014 and March 2016. Patients who had dual positivity for HBs-Ag and hepatitis C virus antibody (HCV-Ab) were considered chronic hepatitis $\mathrm{B} \& \mathrm{C}$ co-infected (HCV \& HBV group).

The study included 72 patients with chronic hepatitis $\mathrm{C}$ and $\mathrm{B}$ virus co-infection. All patients were naive for antiviral treatment. Demographic, possible risk factors, clinical data were collected. Laboratory and imaging data were collected. Data on hepatitis B e antigen (HBe-Ag) status, quantitative HBVDNA polymerase chain reaction (HBVDNA-PCR) and HCV-RNA-PCR assays results were studied.

For comparative purposes, two other matched groups of mono-infection were included as control groups: 80 cases positive only for $\mathrm{HCV}-\mathrm{Ab}$ (HCV-group) and 80 cases positive only for HBs-Ag (HBVgroup). 


\section{Exclusion Criteria}

Identifiable other causes of chronic liver diseases (autoimmune disease, drug hypersensitivity, hemochromatosis, Wilson's disease, alpha-antitrypsin deficiency or alcohol abuse) and patients with history of antiviral therapy.

\section{Serum Markers for $\mathrm{HBV}$ and $\mathrm{HCV}$ Infection}

Serum HBs-Ag was evaluated by commercially available radio-immunoassays or enzyme-linked immunosorbent assay (ELISA) kits (Abbott Diagnostics, North Chicago, IL, USA). Anti-HCV was studied using third-generation ELISA tests (Ortho Diagnostics, Raritan, NJ, USA; and Abbott Diagnostics, North Chicago, IL, USA).

\section{HBV DNA and HCV RNA}

Quantitative assessment of serum HBV DNA and HCV RNA were studied by a realtime PCR assay.

\section{Ethical Considerations}

The study was approved by the Faculty of Medicine Ethical Committee, Assuit University. Informed consent was obtained from all patients.

\section{Statistical Analysis}

Statistical analysis was performed using Statistical Package for the Social Sciences (SPSS- version 17). All data was expressed as mean $\pm \mathrm{SD}$ or frequencies. Continuous variables were compared through Student's $t$ test and proportions were compared with chi-square tests. Results were presented as mean \pm standard deviation (SD). P values of less than 0.05 were considered significant.

\section{Results and Discussion}

The study included 72 patients with chronic hepatitis $\mathrm{C}$ and $\mathrm{B}$ virus co-infection, of whom $90.3 \%$ were male. Their median age was 33 years (mean $38 \pm 11.2$ years). Two other groups of mono-infection were included as control groups: 80 cases positive only for HCV-Ab (HCV-group) and 80 cases positive only for HBs-Ag (HBVgroup).

All patients were native residents of Egypt. Chronic hepatitis C and B virus co-infection was significantly higher in male than female gender in comparison with other groups.

The possible risk factors for infection in all groups are summarized in Table 1.

There was no significant difference between the three groups regarding clinical characteristics except for jaundice and ascites which were significantly higher in the co-infection group $(18.1 \%$ and $13.9 \%$, respectively), as shown in Table 2.

As regards imaging results, normal liver was found in $68.1 \%$ of patients with chronic hepatitis $\mathrm{C}$ and $\mathrm{B}$ virus co-infection, $93.7 \%$ of patients with chronic hepatitis $\mathrm{C}$ virus infection, and in $91.3 \%$ of patients with chronic hepatitis B virus infection. Coarse liver was found in $9.7 \%$ of patients with chronic hepatitis $\mathrm{C}$ and $\mathrm{B}$ virus co-infection, $6.2 \%$ of patients with chronic hepatitis $\mathrm{C}$ virus infection, and in $7.5 \%$ of patients with chronic hepatitis $\mathrm{B}$ virus infection. Hepatomegaly was found in $22.2 \%$ of patients with chronic hepatitis $\mathrm{C}$ and $\mathrm{B}$ virus co-infection, $18.8 \%$ of patients with chronic hepatitis $\mathrm{C}$ virus infection, and in $21.3 \%$ of patients with chronic hepatitis B virus infection. Splenomegaly was found in $13.9 \%$ of patients with chronic hepatitis C and $\mathrm{B}$ virus co-infection, $11.3 \%$ of patients 
with chronic hepatitis $\mathrm{C}$ virus infection, and in $12.5 \%$ of patients with chronic hepatitis B virus infection. Liver cirrhosis was found in $30.6 \%$ of patients with chronic hepatitis C and $\mathrm{B}$ virus co-infection, but only in $3.7 \%$ of patients with chronic hepatitis $\mathrm{C}$ virus infection and $5 \%$ of patients with chronic hepatitis B virus infection. Hepatocellular carcinoma was found in $13.9 \%$ of patients with chronic hepatitis $\mathrm{C}$ and $\mathrm{B}$ virus coinfection, and only in $2.5 \%$ of patients with chronic hepatitis B virus infection. Liver cirrhosis and hepatocellular carcinoma were significantly higher in the co-infection group.

As regards laboratory data, elevated ALT more than three-folds was found in $13.9 \%$ of patients with chronic hepatitis $\mathrm{C}$ and $\mathrm{B}$ virus co-infection, $7.5 \%$ of patients with chronic hepatitis $\mathrm{C}$ virus infection, and in $8.7 \%$ of patients with chronic hepatitis $\mathrm{B}$ virus infection. Elevated AST more than threefolds was found in $15.3 \%$ of patients with chronic hepatitis $\mathrm{C}$ and $\mathrm{B}$ virus co-infection, $8.7 \%$ of patients with chronic hepatitis $\mathrm{C}$ virus infection, and in $8.7 \%$ of patients with chronic hepatitis B virus infection. Reduced serum albumin was found in $29.2 \%$ of patients with chronic hepatitis $\mathrm{C}$ and $\mathrm{B}$ virus co-infection, $3.7 \%$ of patients with chronic hepatitis $\mathrm{C}$ virus infection, and in $5 \%$ of patients with chronic hepatitis $\mathrm{B}$ virus infection. Low platelet count was found in $45.8 \%$ of patients with chronic hepatitis C and $B$ virus co-infection, but only in $12.5 \%$ of patients with chronic hepatitis $\mathrm{C}$ virus infection and $15 \%$ of patients with chronic hepatitis B virus infection.

Reduced serum albumin and low platelet count were significantly higher in the coinfection group, as shown in Table 3.

Both HCV and HBV PCR were positive in $12.9 \%$ of patients with chronic hepatitis $\mathrm{C}$ and $\mathrm{B}$ virus co-infection and both of them were negative in $8.4 \%$ of those patients.

HCV PCR was positive in $75 \%$ of patients with chronic hepatitis $\mathrm{C}$ and $\mathrm{B}$ virus coinfection and in $93.7 \%$ of patients with chronic hepatitis $\mathrm{C}$ alone, while HBV PCR was positive in only $4.2 \%$ of patients with chronic hepatitis $\mathrm{C}$ and $\mathrm{B}$ virus co-infection and in $73.7 \%$ of patients with chronic hepatitis $\mathrm{B}$ alone.

By comparing the $\mathrm{HCV}$ viral load between the co-infection group and the $\mathrm{C}$ group, the viral load was significantly more in the coinfection group than in the $\mathrm{C}$ group.

However, when comparing the HBV viral load between the co-infection group and the B group, the contrast was noted. The HBV viral load was significantly more in the B group than the co-infection group, as shown in Table 4.

Our study disclosed some important observations. First, chronic hepatitis $\mathrm{C}$ and $\mathrm{B}$ virus co-infection had higher prevalence in male than female gender in comparison with the solely chronic hepatitis $\mathrm{C}$ or $\mathrm{B}$ virus infection. However, the possible risk factors for infection as dental manipulations, surgical operations, previous blood transfusion, infection in the family, and tattooing were the same for all groups.

Second, arthralgia, fatigue, and abdominal pain were the main clinical manifestations of all groups. There was no major difference between the three groups regarding clinical characteristics except for jaundice and ascites which were higher in the co-infection group. Third, most of the patients in the mono-infection groups had normal liver on ultrasonographic examination and normal liver function tests. Development of liver cirrhosis and hepatocellular carcinoma was 
higher in the co-infection group. Fourth, demonstrate a dominant role of $\mathrm{HCV}$ in patients with dual HBV-HCV infection. Fifth, the HCV viral load was more in the co-infection group than in the $\mathrm{C}$ group. However, the HBV viral load was more in the B group than the co-infection group.

The results of this study are similar to a previous study by Tyson et al., (2013), who estimated the prevalence and the predictors of $\mathrm{HBV}$ co-infection in a US cohort of $\mathrm{HCV}$-infected patients. They reported that independent associations with HBV coinfection compared with HCV monoinfection were age $\leq 50$ years, male sex, positive HIV status, resident in the south of the country, light alcohol use, lower education level, history of hemophilia, sickle cell anemia or thalassemia, history of blood transfusion, cocaine and other drug use.

Also studies that were done by Deterding et al., (2009), Bhasin et al., (2012) and Maida et al., (2008) reported that HBV shares common modes of transmission with $\mathrm{HCV}$. Blood, body fluids containing visible blood, semen, and vaginal secretions represent a risk of transmission. Both infections are transmitted by percutaneous and mucosal exposure to infective blood or body fluids. The main modes of $\mathrm{HBV}$ and/or $\mathrm{HCV}$ transmission include sexual or close household contact with an infected person, perinatal mother to infant transmission, injecting drug use, and nosocomial exposure. They reported that HBV and/or $\mathrm{HCV}$ can be transmitted by transfusion of infected blood or blood products, sharing unsterilized needles for intravenous drug use, hemodialysis, acupuncture, tattooing, and injuries from contaminated sharp instruments. Maida, et al., (2008) mentioned that the risk factors of dual infection are similar to those of single infection of the two viruses.
Our present study bears some similarities with previous reports by Caccamo, et al., (2014) and Cardoso, et al., (2013), who found that the clinical pattern of the chronic $\mathrm{HBV} / \mathrm{HCV}$ co-infection is indistinguishable from that of a chronic mono-infection. It includes fatigue, vague abdominal discomfort, nausea and vomiting, anorexia, sometimes arthralgia and rash, followed by bleeding gums. This observation can be explained by the fact that dual infection with HBV and HCV leads to mutual suppression of both viruses (Liu and Hou, 2006). However, several studies have suggested that multiple $\mathrm{HBV}$ and $\mathrm{HCV}$ infection may be associated with more severe clinical presentation (Fattovich, 1991 \& Crespo et al., 1994). A Saudi Arabia study showed that the patients with dual HCV and HBV infection had more decompensated liver disease (Mohammed, et al., 1997).

In the present study, our results also showed that the majority of patients in the monoinfection groups had normal liver on ultrasonographic examination and normal liver function tests. Development of liver cirrhosis and hepatocellular carcinoma was higher in the co-infection group. Indeed, several cross-sectional studies found that coinfection is associated with a higher prevalence of liver cirrhosis and hepatic decompensation as compared with $\mathrm{HBV}$ or HCV mono-infection (Zarski et al., 1998; Donato et al., 1998).

Moreover, co-infection has been associated with increased risk of progression of the liver fibrosis and the establishment of cirrhosis (Mohammed et al., 1997; European Association For The Study Of The Liver, 2012) and is an independent predictor of HCC development (Huang et al., 2011; Italian Association for the Study of the Liver, 2010; Aghemo et al., 2014; Weltman et al., 1995). 
Table.1 Demographic characteristics and history of patients in all groups

\begin{tabular}{|c|c|c|c|c|}
\hline Characteristics & $\begin{array}{c}\text { B\&C group } \\
\text { n }(\%)(n=72)\end{array}$ & $\begin{array}{c}\text { HCV group } \\
\mathrm{n}(\%)(\mathrm{n}=\mathbf{8 0})\end{array}$ & $\begin{array}{c}\text { HBV group } \\
\text { n }(\%)(\mathbf{n}=\mathbf{8 0})\end{array}$ & p-value \\
\hline Male gender & $65(90.3 \%)$ & $52(65 \%)$ & $61(76.3 \%)$ & $0.021 *$ \\
\hline Age $($ Mean \pm SD $)$ & $38 \pm 11.2$ & $41 \pm 13.2$ & $33 \pm 12.7$ & 0.542 \\
\hline \multicolumn{5}{|l|}{ Residence } \\
\hline Urban & $27(37.5 \%)$ & $26(32.5 \%)$ & $29(36.3 \%)$ & 0.332 \\
\hline Rural & $45(62.5 \%)$ & $54(67.5 \%)$ & $51(63.7 \%)$ & 0.247 \\
\hline Smoking & $43(59.7 \%)$ & $44(55 \%)$ & $41(51.3 \%)$ & 0.534 \\
\hline \multicolumn{5}{|l|}{ Past history: } \\
\hline Hepatitis & $9(12.5 \%)$ & $9(11.3 \%)$ & $8(10 \%)$ & 0.265 \\
\hline Blood transfusion & $10(13.9 \%)$ & $9(11.3 \%)$ & $7(8.8 \%)$ & 0.064 \\
\hline Surgical operations & $25(34.7 \%)$ & $21(26.3 \%)$ & $15(18.8 \%)$ & 0.073 \\
\hline Dental manipulations & $54(75 \%)$ & $62(77.5 \%)$ & $59(73.8 \%)$ & 0.413 \\
\hline Parenteral drug abuse & $3(4.2 \%)$ & $4(5 \%)$ & $5(6.3 \%)$ & 0.327 \\
\hline Tattooing & $6(8.3 \%)$ & $5(6.3 \%)$ & $7(8.8 \%)$ & 0.422 \\
\hline Schistosomiasis & $8(11.1 \%)$ & $8(10 \%)$ & $7(8.8 \%)$ & 0.328 \\
\hline $\begin{array}{l}\text { Family history of liver } \\
\text { disease }\end{array}$ & $10(13.9 \%)$ & $9(11.3 \%)$ & $11(13.8 \%)$ & 0.265 \\
\hline
\end{tabular}

* Statistically significant

Table.2 Clinical characteristics of patients in all groups

\begin{tabular}{|l|c|c|c|c|}
\hline Characteristics & $\begin{array}{c}\text { B\&C group } \\
\mathbf{n}(\boldsymbol{\%})(\mathbf{n}=\mathbf{7 2})\end{array}$ & $\begin{array}{c}\text { HCV group } \\
\mathbf{n}(\boldsymbol{\%}) \mathbf{( n = 8 0 )}\end{array}$ & $\begin{array}{c}\text { HBV group } \\
\mathbf{n}(\boldsymbol{\%})(\mathbf{n = 8 0})\end{array}$ & p-value \\
\hline Fatigue & $50(69.4 \%)$ & $40(50 \%)$ & $41(51.3 \%)$ & 0.217 \\
Abdominal pain & $31(43 \%)$ & $33(41.3 \%)$ & $30(37.5 \%)$ & 0.341 \\
Arthralgia & $43(59.7 \%)$ & $41(51.3 \%)$ & $38(47.5 \%)$ & 0.513 \\
Hemorrhage: Gums & $3(4.2 \%)$ & $1(1.3 \%)$ & $2(2.6 \%)$ & 0.624 \\
Nose & $2(2.8 \%)$ & $1(1.3 \%)$ & $0(0 \%)$ & 0.078 \\
Abdominal distension & $12(16.7 \%)$ & $10(12.5 \%)$ & $8(10 \%)$ & 0.216 \\
Loss of libido & $7(9.7 \%)$ & $6(7.5 \%)$ & $5(6.3 \%)$ & 0.363 \\
Jaundice & $13(18.1 \%)$ & $3(3.8 \%)$ & $4(5 \%)$ & $0.011 *$ \\
Hepatomegaly & $16(22.2 \%)$ & $15(18.8 \%)$ & $17(21.3 \%)$ & 0.079 \\
Splenomegaly & $10(13.9 \%)$ & $9(11.3 \%)$ & $10(12.5 \%)$ & 0.321 \\
Ascites & $10(\mathrm{a})$ & $1(1.3 \%)$ & $2(2.6 \%)$ & $0.021 *$ \\
Spider naevi & $9(12.5 \%)$ & $9(11.3 \%)$ & $10(12.5 \%)$ & 0.421 \\
Palmar erythema & $3(4.2 \%)$ & $3(3.8 \%)$ & $3(3.8 \%)$ & 0.301 \\
Gynaecomastia & $4(5.6 \%)$ & $3(3.8 \%)$ & $4(5 \%)$ & 0.221 \\
Edema of lower limbs & $5(6.9 \%)$ & $4(5 \%)$ & $5(6.3 \%)$ & 0.426 \\
Subcutaneous hemorrhage & $6(8.3 \%)$ & $6(7.5 \%)$ & $7(8.8 \%)$ & 0.315 \\
\hline
\end{tabular}

* Statistically significant 
Table.3 Imaging and laboratory characteristics of patients in all groups

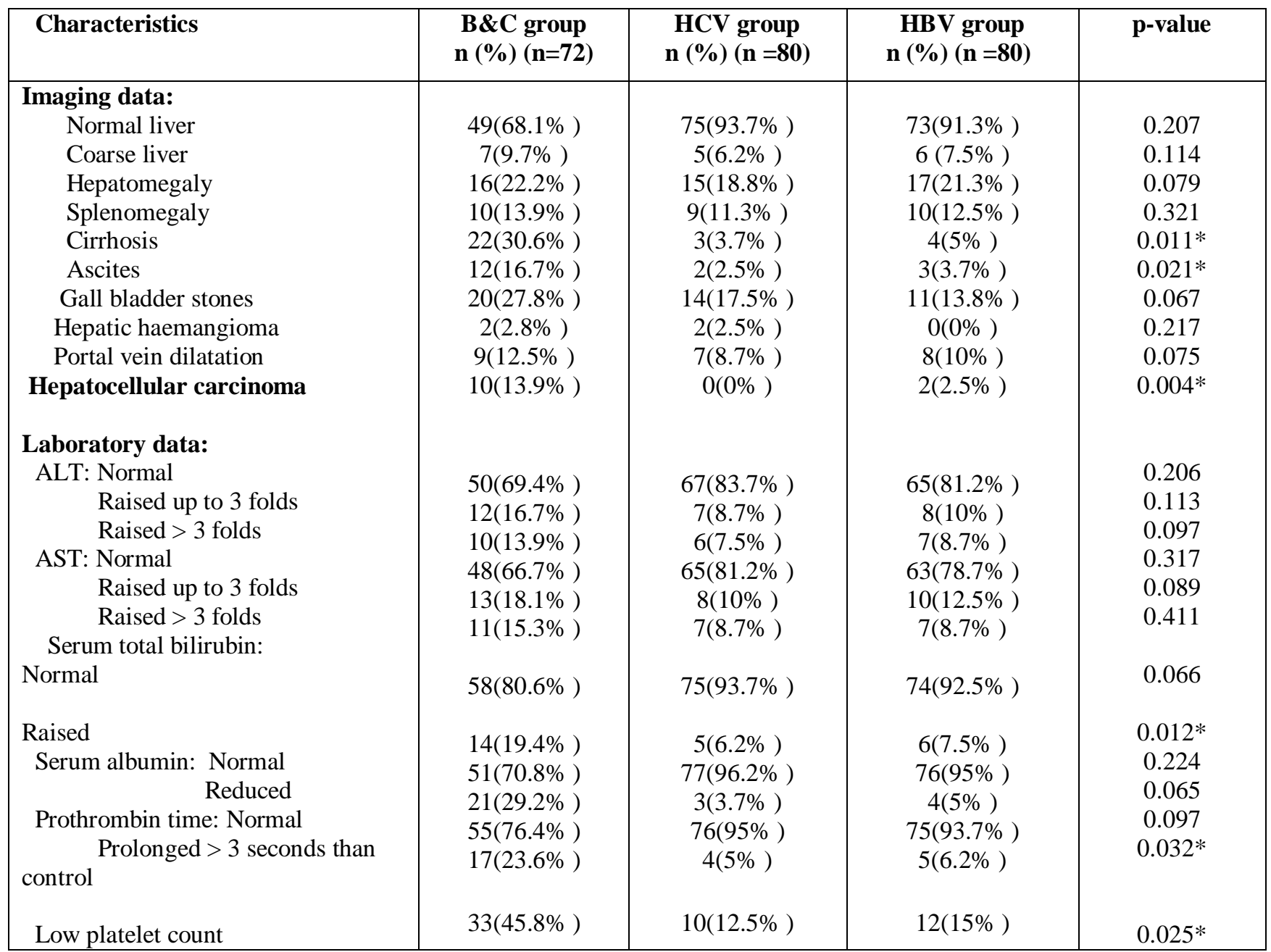

* Statistically significant

Table.4 Virological characteristics of patients in all groups

\begin{tabular}{|l|c|c|c|c|}
\hline Characteristics & $\begin{array}{c}\text { B\&C group } \\
\mathbf{n}(\boldsymbol{\%})(\mathbf{n}=\mathbf{7 2})\end{array}$ & $\begin{array}{c}\text { HCV group } \\
\mathbf{n}(\boldsymbol{\%})(\mathbf{n}=\mathbf{8 0})\end{array}$ & $\begin{array}{c}\text { HBV group } \\
\mathbf{n}(\boldsymbol{\%})(\mathbf{n}=\mathbf{8 0})\end{array}$ & p-value \\
\hline + ve HCV\&HBV PCR & $9(12.9 \%)$ & -- & - & -- \\
+ ve HCV PCR & $54(75 \%)$ & $75(93.7 \%)$ & -- & $0.045^{*}$ \\
+ ve HBV PCR & $3(4.2 \%)$ & -- & $59(73.7 \%)$ & $0.015^{*}$ \\
-ve HCV\&HBV PCR & $6(8.4 \%)$ & -- & - & - \\
HCV-PCR (mean+SD) & $1836923.23 \pm$ & $1524951.26 \pm$ & - & $0.019^{*}$ \\
& 3638760.34 & 2436953.22 & $1946921.26 \pm$ & $0.008^{*}$ \\
HBV-PCR (mean+SD) & $1633913.15 \pm$ & -- & 5639960.24 & \\
\hline
\end{tabular}

* Statistically significant

HBV: Hepatitis B virus

$\mathrm{HCV}$ : Hepatitis $\mathrm{C}$ virus

PCR: Polymerase chain reaction 
There are, however, studies that do not support these conclusions (Villari et al., 1995; Colombari et al., 1993). In a cohort of Egyptians dually infected done by Mekky et al., (2013), patients had no difference regarding the histologic score in comparison to mono-infected patients. These discrepancies can be explained by biases in the design of the studies (small sample size, type of studies as retrospective studies, community or hospital-based studies) and technical reasons (sensitivity of anti-HCV assays). On the other hand, the fact that the co-infection of HBV and HCV ends up in the dominance of either virus and the suppression of the other could partially explain the similarity in histologic findings between co-infected and mono-infected patients (Colombari et al., 1993).

Many epidemiologic studies in patients with HCV and HBV co-infection have documented an increased risk of HCC confirmed by three meta-analyses (Donato et al., 1998; Cho et al., 2011; Shi et al., 2005). Given the role of the chronic necroinflammation and especially cirrhosis in the pathogenesis of HCC together with the higher incidence of cirrhosis and a greater degree of hepatic damage in mono-infection, a synergistic carcinogenic interaction between the two viruses is most probable. The different mechanisms that have been hypothesized as being associated with the development of HBV- or HCV-related HCC suggest that both viruses could play an active role at different steps of the carcinogenic process. Most evidence suggests that $\mathrm{HBV}$ is capable of initiating the neoplastic process, while HCV could act as a promoter, and that they may be synergistic in developing HCC (Shi et al., 2005).

In the present study, we demonstrated that Both HCV and HBV PCR were positive in $12.9 \%$ of patients with chronic hepatitis $\mathrm{C}$ and $\mathrm{B}$ virus co-infection and both of them were negative in $8.4 \%$ of those patients. HCV PCR was positive in $75 \%$ of patients with chronic hepatitis $\mathrm{C}$ and $\mathrm{B}$ virus coinfection and in $93.7 \%$ of patients with chronic hepatitis $\mathrm{C}$ alone, while HBV PCR was positive in only $4.2 \%$ of patients with chronic hepatitis $\mathrm{C}$ and $\mathrm{B}$ virus co-infection and in $73.7 \%$ of patients with chronic hepatitis B alone.

The HCV viral load was more in the coinfection group than in the $\mathrm{C}$ group. However, the HBV viral load was more in the B group than the co-infection group.

This is in agreement with many studies in which the inhibition of HBV replication by HCV was observed (Sagnelli et al., 2000; Pontisso et al., 1998; Jardi et al., 2001). Serum HBV DNA was found more frequently in patients with chronic hepatitis B mono-infection than in patients with chronic hepatitis $\mathrm{C}$ and $\mathrm{B}$ virus co-infection and HBV DNA levels was lower in coinfection than in mono-infection (Sagnelli et al., 2000). Liaw et al., (1994), reported that $\mathrm{HCV}$ infection might suppress HBV or even eliminate and directly interfere with HBV replication and become the sole cause of persistent hepatitis in a small number of patients. Also Shih et al., (1993) found a moderate 2-4 fold reduction of HBV mRNA and $\mathrm{HBV}$ antigen expression in presence of $\mathrm{HCV}$ structure genes and a stronger suppression up to 20 fold of HBV particle secretion.

Zarski et al., (1998) compared virological characteristics of patients with chronic hepatitis $\mathrm{C}$ and $\mathrm{B}$ co-infection with those of patients with chronic $\mathrm{C}$ alone. They found an inverse relationship between the replicative patterns of both viruses. The HCV RNA level was significantly reduced in HBV DNA positive patients compared with HBV DNA negative patients. An 
Italian multicenter case-control study (Sagnelli, et al., 2000), was done on a large number of patients with chronic hepatitis from a multiple hepatitis virus infection that was compared with patients with chronic hepatitis caused by a single virus. In this study, HCV RNA was detected more frequently in patients with anti-HCV positive $(90.7 \%)$ than in patients with HBsAg/anti-HCV positive (65.2\%, $\mathrm{p}<0.001)$.

In conclusion, Chronic hepatitis $\mathrm{C}$ and $\mathrm{B}$ virus co-infection is a complex clinical/virological entity. The risk factors of the co-infection are similar to those of single infection of the two viruses. This coinfection appears to be associated with the most severe forms of chronic liver disease and it is an important risk factor for development of liver cirrhosis and hepatocellular carcinoma. Different, often dynamic virological profiles may be found that are strictly related to the activity of one or both the viruses overtime. Thus, a careful evaluation of the $\mathrm{HCV}$ and $\mathrm{HBV}$ viremia levels is essential for a correct diagnosis, follow-up, and proper therapeutic approach.

\section{References}

Aghemo, A., Colombo, M. 2014. Treatment of patients with dual hepatitis B and C: a step in the right direction. Gut, 63: 380-381.

Bhasin, D., Zhang, X., Ward, S.C., Chang, C.Y. 2012. A case of quadruple viral infections and elevated aminotransferase activities. Semin Liver Dis, 32: 262-266.

Caccamo, G., Saffioti, F., Raimondo, G. 2014. Hepatitis B virus and hepatitis C virus dual infection. World $J$ Gastroenterol., 20(40): 14559-14567.

Cacciola, I., Pollicino, T., Squadrito, G., Cerenzia, G., Orlando, M.E.,
Raimondo, G. 1999. Occult hepatitis $B$ virus infection in patients with chronic hepatitis $\mathrm{C}$ liver disease. New England J. Med., 341: 22-26.

Cardoso, C., Alves, A.L., Augusto, F., et al.,2013. Occult hepatitis B infection in Portuguese patients with chronic hepatitis C liver disease: prevalence and clinical significance. Eur. J. Gastroenterol. Hepatol., 25:142-146.

Chen, S.Y., Kao, C.F., Chen, C.M., Shih, C.M., Hsu, M.J., Chao, C.H., Wang, S.H., You, L.R., Lee, Y.H. 2003. Mechanisms for inhibition of hepatitis $B$ virus gene expression and replication by hepatitis $\mathrm{C}$ virus core protein. J. Biol. Chem., 278: 591-607.

Cho, L.Y., Yang, J.J., Ko, K.P., et al., 2011. Coinfection of hepatitis $\mathrm{B}$ and $\mathrm{C}$ viruses and risk of hepatocellular carcinoma: systematic review and meta-analysis. Int. J. Cancer, 128:176-184.

Chu, C.J., Lee, S.D.2008. Hepatitis B virus/hepatitis $\mathrm{C}$ virus coinfection: epidemiology, clinical features, viral interactions and treatment. $J$. Gastroenterol. Hepatol., 23: 512-520.

Colombari, R., Dhillon, A.P., Piazzola, E.,et al., 1993. Chronic hepatitis in multiple virus infection: histopathological evaluation. Histopathol., 22: 319-325.

Crespo, J., Lozano, J.L., de la Cruz, F., Rodrigo, L., Rodriguez, M., San Miguel, G., Artinano, E., et al. 1994. Prevalence and significance of hepatitis $\mathrm{C}$ viremia in chronic active hepatitis B. Am. J. Gastroenterol., 89: 1147-1151.

Crockett, S.D., Keeffe, E.B. 2005. Natural history and treatment of hepatitis B virus and hepatitis $C$ virus coinfection. Annals of Clinical Microbiology and Antimicrobials, 4: 13.

Deterding, K., Pothakamuri, S.V., Schlaphoff, V., Hadem, J., Metzler, 
F., Bahr, M.J., Manns, M.P., Cornberg, M., Wedemeyer, H. 2009. Clearance of chronic HCV infection during acute delta hepatitis. Infect., 37: 159-162.

Donato, F., Boffetta, P., Puoti, M. 1998. A meta-analysis of epidemiological studies on the combined effect of hepatitis $\mathrm{B}$ and $\mathrm{C}$ virus infections in causing hepatocellular carcinoma. Int. J. Cancer, 75: 347-354.

European Association for The Study Of The Liver, 2012. EASL clinical practice guidelines: Management of chronic hepatitis B virus infection. J. Hepatol., 57: 167-185.

Fattovich, G., Tagger, A., Brollo, L., Giustina, G., Pontisso, P., Realdi, G., Alberti, A. 1991. Hepatitis C virus infection in chronic hepatitis $\mathrm{B}$ virus carriers. J. Infect. Dis., 163: 400-402.

Gordon, S.C., Sherman, K.E. 2009. Treatment of $\mathrm{HBV} / \mathrm{HCV}$ coinfection: releasing the enemy within. Gastroenterol., 136: 393-396.

Huang, Y.T., Jen, C.L., Yang, H.I., Lee, M.H., Su, J., Lu, S.N., Iloeje, U.H., Chen, C.J. 2011. Lifetime risk and sex difference of hepatocellular carcinoma among patients with chronic hepatitis B and C. J. Clin. Oncol., 29: 36433650 .

Italian Association for the Study of the Liver; Italian Society of Infectious, Tropical Diseases; Italian Society for the Study of Sexually Transmitted Diseases, 2010. Practice guidelines for the treatment of hepatitis C: recommendations from an AISF/ SIMIT/SIMAST Expert Opinion Meeting. Dig. Liver Dis., 42: 81-91.

Jardi, R., Rodriguez, F., Buti, M., Costa, X., Cotrina, M., Galimany, R., Esteban R. 2001. Role of hepatitis B, C, and D viruses in dual and triple infection: influence of viral genotypes and hepatitis B precore and basal core promoter mutations on viral replicative interference. Hepatol., 34: 404-410.

Lee, C.A., Kernoff, P.B., Karayiannis, P., Farci, P., Thomas, H.C. 1985. Interactions between hepatotropic viruses in patients with haemophilia. J. Hepatol., 1: 379-384.

Liaw, Y.F., Tsai, S.L., Chang, J.J., Sheen, I.S., Chien, R.N., Lin. D.Y., Chu, C.M. 1994. Displacement of hepatitis $\mathrm{B}$ virus by hepatitis $\mathrm{C}$ virus as the cause of continuing chronic hepatitis. Gastroenterol.,106: 1048-1053.

Liu, Z., Hou J. 2006 .Hepatitis B Virus (HBV) and Hepatitis C Virus (HCV) Dual Infection. Int. J. Med. Sci., 3(2): 57-62.

Maida, I., Ríos, M.J., Pérez-Saleme, L., Ramos,. B, Soriano, V., Pegram, P.S., Mura, M.S., Sánchez-Margalet, V., Saldívar-Cornejo, I., Wilkin, A., Babudieri, S., Núñez, M. 2008. Profile of patients triply infected with HIV and the hepatitis $\mathrm{B}$ and $\mathrm{C}$ viruses in the HAART era. AIDS Res. Hum. Retroviruses, 24: 679-683.

Mekky, M.A., Nasr, A.M., Saleh, M.A., et al. 2013. Virologic and histologic characterization of dual hepatitis B and $\mathrm{C}$ co-infection in Egyptian patients. Arab. J. Gastroenterol., 14: 143-147.

Mohamed, Ael S., Al Karawi, M.A., Mesa, G.A. 1997. Dual infection with hepatitis C and B viruses: clinical and histological study in Saudi patients. Hepatogastroenterol., 44: 1404-1406.

Pontisso, P., Gerotto, M., Benvegnu, L., Chemello, L., Alberti, A. 1998.Coinfection by hepatitis B virus and hepatitis $\mathrm{C}$ virus. Antivir. Ther., 3(Suppl 3):137-142.

Sagnelli, E., Coppola, N., Scolastico, C., Filippini, P., Santantonio, T., 
Stroffolini, T., Piccinino, F. 2000. Virologic and clinical expressions of reciprocal inhibitory effect of hepatitis $\mathrm{B}, \mathrm{C}$, and delta viruses in patients with chronic hepatitis. Hepatol., 32: 11061110.

Schüttler, C.G., Fiedler, N., Schmidt, K., Repp, R., Gerlich, W.H., Schaefer, S. 2002. Suppression of hepatitis B virus enhancer 1 and 2 by hepatitis $C$ virus core protein. J. Hepatol., 37: 855-862.

Sheen, I.S., Liaw, Y.F., Chu, C.M., Pao, C.C. 1992. Role of hepatitis C virus infection in spontaneous hepatitis B surface antigen clearance during chronic hepatitis B virus infection. $J$. Infect. Dis., 165: 831-834.

Shi, J., Zhu, L., Liu, S., Xie, W.F. 2005. A meta-analysis of case-control studies on the combined eff ect of hepatitis B and $\mathrm{C}$ virus infections in causing hepatocellular carcinoma in China. $\mathrm{Br}$. J. Cancer, 92: 607-612.

Shih, C.M., Chen, C.M., Chen, S.Y., Lee, Y.H. 1995. Modulation of the transsuppression activity of hepatitis C virus core protein by phosphorylation. J. Virol., 69: 1160-1171.

Shih, C.M., Lo, S.J., Miyamura, T., Chen, S.Y., Lee, Y.H. 1993. Suppression of hepatitis B virus expression and replication by hepatitis $\mathrm{C}$ virus core protein in HuH-7 cells. J. Virol., 67: 5823-5832.

Tyson, G.L., Kramer, J.R., Duan, Z., Davila,
J.A., Richardson, P.A., El- Serag, H.B. 2013. Prevalence and predictors of hepatitis B virus coinfection in a United States cohort of hepatitis C virus infected patients. Hepatol., 58: 538-545.

Villari, D., Pernice, M., Spinella, S. 1995. Chronic hepatitis in patients with active hepatitis $\mathrm{B}$ virus and hepatitis $\mathrm{C}$ virus combined infections: a histological study. Am. J. Gastroenterol., 90: 955-958.

Weltman, M.D., Brotodihardjo, A., Crewe, E.B., Farrell, G.C., Bilous, M., Grierson, J.M., Liddle, C. 1995. Coinfection with hepatitis $\mathrm{B}$ and $\mathrm{C}$ or $\mathrm{B}, \mathrm{C}$ and delta viruses results in severe chronic liver disease and responds poorly to interferon-alpha treatment. $J$. Viral. Hepat., 2: 39-45.

Wu, J.C., Chen, C.L., Hou, M.C., Chen, T.Z., Lee, S.D., Lo, K.J. 1994. Multiple viral infection as and subfulminant viral hepatitis in an area endemic for hepatitis B: application and limitations of the polymerase chain reaction. Hepatol., 19: 836-840.

Zarski, J.P., Bohn, B., Bastie, A., Pawlotsky, J.M., Baud, M., Bost- Bezeaux, F., Tran van Nhieu, J., Seigneurin, J.M., Buffet, C., Dhumeaux, D. 1998. Characteristics of patients with dual infection by hepatitis $\mathrm{B}$ and $\mathrm{C}$ viruses. J. Hepatol., 28: 27-33.

\section{How to cite this article:}

Khairy H. Morsy and Mohamed A.A. Ghaliony. 2016. Clinical, Laboratory, and Virological Profiles of Patients with Hepatitis C and B Co-infection in Upper Egypt. Int.J.Curr.Microbiol.App.Sci. 5(5): 419-429. doi: http://dx.doi.org/10.20546/ijcmas.2016.505.044 